\title{
INTERFACES ORAL E ESCRITA NA DELEGACIA DA MULHER
}

Rosineide de Melo*

\begin{abstract}
RESUMO: A Delegacia de Polícia de Defesa da Mulher surgiu na década de 1980 com a finalidade de atender as mulheres vítimas de violência. Nosso estudo procurou investigar a relação estabelecida entre os depoimentos orais das mulheres que recorrem à Delegacia para formalizarem sua queixa em confrontação aos respectivos Boletins de Ocorrência e Termos Circunstanciados - registros escritos elaborados pelas escrivãs de polícia. Os registros formais e padronizados não relatam fielmente o discurso da vítima. À luz dos conceitos do pensador russo Mikhail Bakhtin e de seu Círculo sobre dialogismo e gênero do discurso, analisamos como os discursos das mulheres são reformulados e, nesse processo, adquirem sentidos heterogêneos.
\end{abstract}

PALAVRAS-CHAVE: discurso; reformulação; vez; mulher.

\section{Introdução}

Este artigo tem por objetivo apresentar os resultados de Polícia de Defesa da Mulher, no período de 1999 a 2001. Nosso trabalho, inserido na linha de pesquisa "linguagem nas relações de

* Lingüística Aplicada e Estudos da Linguagem - LAEL/PUCSP. Doutoranda. Bolsista pela CAPES. Professora do Centro Universitário Fundação Santo André.

1 Delegacia de Polícia: Defesa da Mulher? Um enfoque dialógico. Dissertação de Mestrado defendida em 2001, sob a orientação da Prof $^{a}$ Dr $^{a}$ Beth Brait. 
Meso, Rosineide de. Interfaces oral e escrita na delegacia da mulher

trabalho" do LAEL, tratou de focalizar, de uma perspectiva enunciativo-dialógica, os discursos das mulheres vítimas de violência que recorrem às Delegacias de Mulheres para registrarem suas queixas. A motivação para esse estudo surgiu da consideração de que a questão ideológica de criação dessa delegacia e de sua especificidade nos proporcionaria um frutifero estudo bakhtiniano sobre a linguagem. De fato, a pesquisa tornou-se fascinante e desafiadora do ponto de vista do processo e dos resultados da análise e interpretação dos fatos lingüísticos.

\section{O cenário da pesquisa}

A Delegacia de Polícia de Defesa da Mulher (DDM) foi criada em São Paulo pela Lei Estadual $n^{0} 5.467$, de 24 de dezembro de 1986, com o objetivo de atender as pessoas do sexo feminino que procuram auxíliọ e orientação, encanininhando-as aos órgãos competentes, bem como investigar e apurar os delitos contra a pessoa do sexo feminino, de autoria conhecida, incerta ou não sabida, conforme texto do Decreto $\mathrm{n}^{\circ} 29.981$, de $1^{\circ}$ de junho de 1989 . O surgimento dessa delegacia especializada está vinculado aos movimentos feministas anteriores à década de 1980 .

Nos anos de 1970, uma série de assassinatos decorrentes de violência doméstica passou a ser noticiada pela imprensa, sendo o crime de Ângela Diniz, em 1976, o de maior repercussão. Nessa ocasião, os movimentos feministas se intensificam em torno do tema "sexualidade e violência". Os grupos organizados em defesa da mulher passaram a exigir dos governos o estabelecimento de políticas públicas na área da violência contra a mulher. Surgem, assim, em São Paulo, o Conselho Estadual da Condição Feminina (1983) e o Programa de Atendimento Integral à Saúde da Mulher - PAISM (1984). Em 1986 foi criado, em Brasília, o Conselho Nacional dos Direitos da Mulher e no mesmo ano, em São Paulo, é inaugurado o Centro de 
Melo, Rosineide de. Interfaces oral e escrita na delegacia da mulher

que, segundo a delegada, pela especificidade da função exigir-se-ia um homem para o cargo.

Para viabilizarmos essa pesquisa, tivemos de seguir alguns procedimentos: primeiro, obter autorização da delegada da unidade para a realização da pesquisa; segundo, obter consentimento das escrivãs de polícia para acompanhar os depoimentos das vítimas; terceiro, obter autorização por escrito das vítimas para acompanhar e gravar seus depoimentos e reproduzir por fotocópia os registros advindos dos depoimentos.

\section{A pesquisa}

A pesquisa de campo consistiu da gravação dos depoimentos orais das mulheres vitimas de violência e das respectivas cópias dos Boletins de Ocorrência (B.O.) e Termos Circunstanciados (T.C.) registrados pelas escrivãs de polícia. Nosso corpus foi formado por seis horas de gravação referentes a 15 depoimentos orais, 11 Boletins de Ocorrências, quatro Termos Circunstanciados e 12 Boletins de Ocorrência obtidos em arquivo, além de resumos e cópias de laudos médicos. Um recorte inicial para a concretização dessa pesquisa consistiu em excluir casos de estupro e de atentado violento ao pudor. Do conjunto desses fatos lingüîsticos, trabalhamos, na análise, com quatro depoimentos orais e seus respectivos B.O's e T.C's. O critério norteador desse recorte foi o fato de que somente esses quatro depoimentos tinham gerado os dois tipos de registros escritos.

A coleta de dados ocorreu durante o mês de setembro de 1999 somente com vitimas de violência doméstica, ou seja, mulheres

4 A identificação da unidade pesquisada, bem como das funcionárias e vítimas foi mantida em sigilo absoluto, norteada por princípios éticos e como requisito para a realização da pesquisa. 
Rev. ANPOLL, n 18, p. 183-216, jan./jun. 2005.

agredidas pelos maridos ou companheiros. Antes de realizarmos a gravação, conversávamos com a mulher, na sala de espera. Explicávamos a finalidade daquele trabalho, apresentávamos o termo de autorização e a convidâvamos a participar da pesquisa. Nessa primeira interação, era comum ouvirmos as queixas da vitima e já nos situávamos um pouco de sua história. Ficávamos aguardando até o chamado da escrivã. O relato da vítima e a simultânea datilografia da ocorrência pela escrivã aconteciam na sala destinada a esse fim ${ }^{4}$, assistiamos ao depoimento com o gravador ligado. Ao final do depoimento, a mulher era dispensada e nós voltávamos à sala de espera. Das 18 vitimas contatadas, 15 autorizaram as gravações. Acompanhamos depoimentos conduzidos por quatro escrivãs. Ao final de cada periodo de atendimento providenciávamos a cópia dos registros correspondentes às gravações executadas.

O procedimento de trabalho na unidade pesquisada era feito de duas formas:

a) primeiro atendimento:quando se tratava da primeira vez que a mulher procurava a delegacia, ela era atendida numa recepção, local onde retirava uma senha. Ao ser convocada, a mulher se dirigira à sala dos depoimentos. A escrivã indagava sobre a queixa e anotava as informações numa folha de rascunho identificada por "resumo". Nos casos de alegação de agressão física, a mulher era orientada a providenciar exame de corpo de delito, procurar advogado e apresentar nome e endereço do agressor e de testemunhas para a elaboração de intimaçōes. A escrivã agendava um retorno para que, nesse segundo encontro, pudesse ser lavrado o B.O. Nos casos de agressão verbal ou ameaça, a

5 As salas de depoimentos eram, na verdade, saletas separadas por divisórias, de modo que os depoimentos das salas ao lado poderiam ser ouvidos na íntegra, neutralizando qualquer tentativa de discrição dos relatos. Era comum,também, as escrivãs simultaneamente à coleta dos relatos estabelecerem entre si conversas paralelas de ordem administrativa ou pessoal. 
MEL, Rosineide de. Interfaces oral e escrita na delegacia da mulher

escrivã registrava o B.O. imediatamente, entregava-o para a vítima ler e assinar e em seguida passava para a delegada assiná-lo também;

b) atendimento agendado: no horărio marcado, a escrivã não necessariamente a mesma que fizera o primeiro atendimento, chamava a mulher na sala dos depoimentos, retomava os motivos da queixa confirmando algumas informações, solicitava o laudo do exame de corpo de delito e confirmava a presença do acusado e das testemunhas. Em seguida, a escrivã passava datilografar o B.O. c o T.C., sendo que neste último deveria constar se a vítima daria prosseguimento ao processo de indiciamento do acusado ou não. Em caso afirmativo, as testemunhas eram chamadas e seus depoimentos registrados. Em caso negativo, as testemunhas eram dispensadas.

A análise dos fatos lingüísticos visou a três pontos principais:

a) verificar como o processo de reformulação do oral para o escrito contribuiu para a constituição de sentidos heterogêneos no discurso;

b) identificar os elementos estáveis dos enunciados que não só compunham tema, forma composicional e estilo, como também caracterizavam a atividade discursiva da DDM;

c) apontar as pistas lingüisticas e extralingüísticas que revelavam as vozes no discurso das mulheres na DDM.

Nossas inquietações nessa pesquisa repousavam em duas questões básicas: 1) os depoimentos orais das vítimas eram transformados em registros escritos sob as formas de B.O. e de T.C. Na confluência de vozes (das mulheres vitimas $\mathrm{x}$ mulheres escrivãs) existiam apagamentos, modificações, acréscimos. Quais os sentidos construídos nessa reformulação do discurso oral para o discurso escrito? 2) De que forma a DDM - um órgão criado para dar voz às vítimas de violência - representava discursivamente essa voz da mulher? 
Rev. ANPOLL, n 18, p. 183-216, jan./jun. 2005.

\section{Fundamentação teórica}

Norteamo-nos, nessa pesquisa, pela teoria enunciativodialógica de Bakhtin e seu Círculo e recorremos a outras áreas da ciência e, mesmo dentro da lingüística, a linhas diferenciadas de pesquisa sempre que necessário, ratificando o caráter dialógico inerente de uma proposta bakhtiniana. Assim, trabalhamos com as noções de gênero do discurso e suas implicações, com as várias formas de dialogismo, privilegiando o discurso citado, com a noção de reformulação proposta por Maingueneau e Authier-Revuz, com o conceito de designação e com elementos da Análise da Conversação. Para transcrevermos os depoimentos orais, recorremos às normas de transcrição propostas pelo Prof. Dino Pretti no Projeto NURC (Projeto de Estudo da Norma Lingüística Urbana Culta de São Paulo). Para entendermos o contexto da instituição pesquisada tivemos longos diálogos com o Direito, a História e a Sociologia, os quais apareceram implicitamente na primeira parte deste artigo.

Um princípio básico do pensamento bakhtiniano é a consideração de que o discurso "a língua em sua integridade concreta e viva” (BAKHTIN, 1997, p. 181) do eu não é puro, pois traz em si voz do outro, isso equivale a dizer que o discurso é constitutivamente dialógico e o lugar privilegiado de encontro das mais diversas vozes, o que faz dele um evento social, político, filosófico, religioso, ideológico.

Bakhtin entende que o dialogismo implicado no discurso se faz representar de várias formas e em vários graus:

A transmissão e o exame dos discursos de outrem, das palavras de outrem, é um dos temas mais divulgados e essenciais da fala humana. Em todos os dominios da vida e da criação ideológica, nossa fala contém em abundância palavras de outrem, transmitidas com todos os graus variáveis de precisão e imparcialidade (BAKHTIN, 1998, p. 139). 
MeLo, Rosineide de. Interfaces oral e escrita na delegacia da mulher

Uma forma privilegiada de dialogismo é aquela do "discurso no discurso", a forma marcada da presença do outro no discurso do eu, ou seja, o discurso citado ${ }^{6}$. Essa discussão é tão séria para o Círculo que em Marxismo e filosofia da linguagem, Bakhtin/ Volochinov dedicam o capítulo 9 para o "Discurso do outrem".

Aproximamos Bakhtin, Authier-Revuz e D. Maingueneau nas considerações acerca do discurso citado por apresentarem convergências na forma de abordagem desse assunto, embora respeitadas suas especificidades e suas filiações. Apresentamos no quadro a seguir as concepções de cada autor de forma bastante resumida e somente contemplando as três formas clássicas do discurso citado ${ }^{7}$ :

Quadro 1 - Discurso citado por Bakhtin, Authier-Revuz e Maingueneau:

\begin{tabular}{|c|c|c|c|}
\hline Definiçóes & Bakthin & Authier-Revuz ${ }^{8}$ & Maingueneau \\
\hline \begin{tabular}{|l} 
Discurso \\
Direto (DD)
\end{tabular} & $\begin{array}{l}\text { Discurso "preparado": } \\
\text { (uso de itálico, de si- } \\
\text { nais de pontuação); } \\
\text { "esvaziado": o autor } \\
\text { joga sobre o outro a } \\
\text { responsabilidade do } \\
\text { que é dito. }\end{array}$ & $\begin{array}{l}\text { Discurso complexo. } \\
\text { Não pode ser objetivo } \\
\text { porque reproduz a } \\
\text { materialidade exata do } \\
\text { enunciado, mas não o } \\
\text { ato de enunciação. o } \\
\text { enunciador relata um } \\
\text { outro ato de enuncia- } \\
\text { ção e, mesmo usando } \\
\text { suas próprias palavras, } \\
\text { faz menção às palavras } \\
\text { que relata. }\end{array}$ & $\begin{array}{l}\text { Discurso no qual o su- } \\
\text { jeito falante se apresen- } \\
\text { ta como o locutor de } \\
\text { sua enunciação, mas } \\
\text { delega a responsabili- } \\
\text { dade da tala citada a } \\
\text { um segundo locutor, o } \\
\text { do discurso direto. Pro- } \\
\text { cura-se um pseudodis- } \\
\text { tanciamento: } \\
\text { apresenta-se a citação, } \\
\text { mas não se garante ob- } \\
\text { jetividade. Há uma rup- } \\
\text { tura entre as duas si- } \\
\text { tuações de enunciação. }\end{array}$ \\
\hline
\end{tabular}

6 Dedicamos uma parte considerável em nossa dissertação para a discussão do discurso citado, pelo fato de que, tanto na voz da vítima como na voz da escrivã, havia uma predominância desse tipo de discurso.

7 Em nossa dissertação, mencionamos as outras formas de discurso citado concebidas por Maingueneau e Authier-Revuz: discurso direto livre, modalização em discurso segundo, modalização autominica em discurso segundo e as formas híbridas.

8 Authier-Revuz e Maingueneau adotam a diferenciação proposta por Benveniste entre enunciado (produto da enunciação) e enunciação (ação e momento da pro- 
Rev. ANPOLL, $n^{0} 18$, p. 183-216, jan./jun. 2005.

\begin{tabular}{|c|c|c|c|}
\hline $\begin{array}{l}\text { Discurso } \\
\text { Indireto } \\
\text { (DI) }\end{array}$ & $\begin{array}{l}\text { Discurso que requer } \\
\text { elaboração. Pode ser } \\
\text { "analisador do conteú- } \\
\text { do" e "analisador da } \\
\text { expressão",. Discurso } \\
\text { introduzido pela con- } \\
\text { junção precedida do } \\
\text { verbo. }\end{array}$ & $\begin{array}{l}\text { Trata-se de uma opera- } \\
\text { ção de reformulação- } \\
\text { tradução do discurso } \\
\text { do outro que é relata- } \\
\text { do. O enunciador } \\
\text { reformula as palavras } \\
\text { do outro. }\end{array}$ & $\begin{array}{l}\text { Constitui-se de uma } \\
\text { tradução da enuncia- } \\
\text { ção citada: não são as } \\
\text { palavras do enunciador } \\
\text { citado que são relata- } \\
\text { das, mas sim o conteú- } \\
\text { do do pensamento. Es- } \\
\text { trutura formada por } \\
\text { verbo dicendi mais con- } \\
\text { junção integrante. }\end{array}$ \\
\hline \begin{tabular}{|l|} 
Discurso \\
Indireto \\
Livre (DIL)
\end{tabular} & $\begin{array}{l}\text { Discurso em que há } \\
\text { uma convergência in- } \\
\text { terferente de dois dis- } \\
\text { cursos com diversa } \\
\text { orientação do ponto de } \\
\text { vista da entoação. Não } \\
\text { se trata de mistura } \\
\text { entre DD + DI, mas } \\
\text { sim de uma postura } \\
\text { assumida pelo autor: } \\
\text { quando o eu apresen- } \\
\text { ta a enunciação do ou- } \\
\text { tro, passa a encarre- } \\
\text { gar-se dela. }\end{array}$ & $\begin{array}{l}\text { Forma não marcada, } \\
\text { puramente interpre- } \\
\text { tativa de representação } \\
\text { de um outro ato de } \\
\text { enunciação e só pode } \\
\text { ser caracterizada den- } \\
\text { tro do contexto discur- } \\
\text { sivo. }\end{array}$ & $\begin{array}{l}\text { Não existem marcas } \\
\text { lingüisticas específicas, } \\
\text { só pode ser percebido } \\
\text { no contexto, é o caso } \\
\text { mais típico de } \\
\text { hibridação. Nesse tipo } \\
\text { de discurso, há duas } \\
\text { vozes mescladas, não } \\
\text { sendo possível dizer } \\
\text { qual é a voz do } \\
\text { enunciador citado e } \\
\text { qual é do citante. O lei- } \\
\text { tor só percebe a } \\
\text { dualidade pela discor- } \\
\text { dância entre as duas }\end{array}$ \\
\hline
\end{tabular}

Fonte: Guadro elaborado por nós com base nas obras mencibuzedas nas Referências Bibliográficas.

Todas as formas de apresentar o "discurso do outro" pressupõem um processo de reformulação. O Círculo bakhtiniano não traz explicitamente essa discussão, recorremos a Maingueneau e AuthierRevuz para nos auxiliar na compreensão desse conceito.

Segundo MAINGUENEAU (1998), a reformulação no discurso refere-se a uma transformação de uma unidade discursiva em outra "equivalente"; o adjetivo aprece entre aspas, exatamente porque não hâ uma "equivalência" direta e objetiva entre um discurso e sua reformulação - nesta já está implicada uma alteração e já tem impregnada a voz do outro. Considerando nosso universo pesquisado e nossos objetos, a reformulação ocorrida nos discursos da delegacia

dução de enunciados). A concepção do Círculo, anterior à de Benveniste, não considera essa divisão. 
Melo, Rosineide de. Interfaces oral e escrita na delegacia da mulher

não se deu apenas de um tipo de discurso para um outro do mesmo tipo "equivalente", a reformulação foi brusca à medida que se passou do discurso oral para o discurso escrito, do relato da vítima para o registro da escrivã, envolvendo sujeitos discursivos diferentes e com orientação, apreciação e entoações diversas.

AUTHIER-REVUZ (1998) apresenta pontos importantes sobre a reformulação, os quais foram ao encontro de nossas reflexões durante o desenvolvimento da pesquisa. A autora concebe a reformulação como mais uma das muitas formas dialogismo, reconhece que é um tipo de discurso marcado por dupla determinação à medida que se fala pelo outro e para um outro. Nessa perspectiva, a reformulação é necessária como instrumento mediador entre um discurso fonte (em nosso caso, depoimento da vítima) e um discurso final (inquérito para o juiz), a mediação está na reformulação que escrivã faz da linguagem cotidiana do depoimento oral da vitima em linguagem juridica escrita no B.O. e T.C. Revuz complementa que nas reformulações há supressões, adições, substituições, apagamentos e/ou fragmentos do discurso fonte - pensando em Bakhtin, a reformulação já estaria impregnada da entoação apreciativa do sujeito.

Outra concepção importante para a análise dos fatos lingüísticos em nossa dissertação foi o conceito de designação. De acordo com Mainguenau "os locutores de uma língua dispõem de diversos meios para designar um referente, de diversos modos de apresentação de um referente"9 (MAINGUENEAU, 1998, p. 157). A diversidade de designações não corresponde necessariamente à diversidade de referentes: um mesmo indivíduo pode ser identificado de várias formas e, ainda, as designações podem ser de vários tipos:

9 Tradução feita por nós para fins didáticos. "Les locuteurs dúne langue disposent em effet de divers moyens pour desgner um référent, de divers modes de donation de ce référent" MAINGUENEAU, Dominique. Analyser les textes de communication, Paris: Dunod.1998 (grifos do autor). 
Rev. ANPOLL, n' 18, p. 183-216, jan./jun. 2005.

nomes próprios, pronome, substantivos e "descrições definidas", estas, apresentam como característica a generalização, agregando uma pluralidade de propriedades de um grupo ou de um tipo de indivíduo. Nos discursos da delegacia, há uma predominância das descrições definidas: vítima (para a mulher agredida) autor, acusado ou indiciado (para o agressor) e a autodesignação autoridade policial ou escrivã para a agente policial.

Todos esses aspectos unem-se na concepção de gênero do discurso proposto pelo Círculo bakthiniano. Ressaltamos que não tivemos a pretensão de classificar "o" gênero do discurso da delegacia, limitamo-nos a estudar os discursos que lá circulavam tendo como categoria de análise também os componentes do gênero: tema, forma composicional e estilo.

Em nosso ver, a noção de gênero do discurso é uma questão fundante no pensamento dos teóricos russos, uma vez que eles apregoam que a sociedade se organiza em esferas comunicativas ou atividades de linguagem por onde os enunciados circulam. Os gêneros existem à medida que organizam os enunciados e "[os gêneros] nos são dados quase como nos é dada a lingua materna" (BAKHTIN, 1997, p.301). Essa concepção, impregnada das perspectivas social e dialógica, implica as condições de produção em que o discurso se construiu, as condições de circulação e recepção desses discursos. O enunciado vai refletir as finalidades de cada atividade de linguagem ou esfera por intermédio do tema, do estilo e da forma verbal, "cada esfera de utilização da língua elabora seus tipos relativamente estáveis de enunciados, sendo isso que denominamos gêneros do discurso" (BAKHTIN, 1997, p.278). Pela perspectiva bakhtiniana, nosso entendimento do tema não se confunde com assunto do enunciado, ou seja, ultrapassa a simples identificação sobre "do que se fala", refere-se ao sentido do/no discurso construído. O estilo, por sua vez, é a marca que caracteriza determinado enunciado na cadeia de sua evolução enquanto gênero discursivo, não se trata de identificações de traços individuais - embora não haja uma 
Mewo, Rosineide de. Interfaces oral e escrita na delegacia da mulher

negação da singularidade que o constitui - mas de algo que o caracteriza no diálogo com a tradição. A forma composicional refere-se à estrutura lexical, sintática e semântica presente em determinados enunciados e, portanto, nos gêneros. De todos os elementos, consideramos a forma composicional o mais estável deles.

Das escolhas teóricas convocadas para o diálogo com nosso corpus, falta-nos mencionar a contribuição da Análise da Conversação - uma vertente dos estudos da linguagem. A Análise da Conversação centra-se nos estudos das interações verbais orais e estabelece conceitos e parâmetros para a realização de uma descrição e análise dessas "conversas". Por essa vertente, a conversação é definida como um

evento de fala especial: corresponde a uma interação verbal centrada, que se desenvolve durante o tempo em que dois ou mais interlocutores voltam sua atenção para uma tarefa comum, que é a de trocar idéias sobre um determinado assunto (RODRIGUES, 1993, p.18).

Esse evento de fala só pode ocorrer inserido num contexto situacional, ou seja, num ambiente envolvido pela situação imediata e específica, pelos participantes e papéis sociais que desempenham naquela interação, pelo processo interacional que os envolve e envolve aquele evento. A Análise da Conversação examina como se desenvolvem os turnos - alternâncias de falas - como os participantes se revezam nos papéis de falantes e ouvintes, quem tem a preferência do turno ou quem toma o turno de quem; vai se preocupar também com o tópico discursivo "aquilo acerca do que se está falando" (FÁVERO, 1993, p.38).

A Análise da Conversação dispõe de muitas outras categorias: marcadores conversacionais, que dão sustentação e continuidade ao conteúdo do discurso, funcionando como articuladores do texto conversacional, de acordo com URBANO (1993); a reparação entendida como uma correção ou autocorreção de um "erro" (BARROS, 
Rev. ANPOLL, nº 18, p. 183-216, jan./jun. 2005.

1993); as interrupções - fenômeno típico da fala. Elegemos essas categorias da Análise da Conversação para dar suporte à análise do corpus oral.

Muito longe de realizar uma abordagem abrangente sobre a Análise da Conversação ou sobre quaisquer teorias e conceitos mencionados aqui, pretendemos, neste artigo, explicitar nossas escolhas teóricas e ancorar o "lugar de onde falamos". Temos clareza de que essas concepções merecem um aprofundamento e um debate amplo, mas optamos por destacar os aspectos mais relevantes e imprescindiveis ao entendimento do percurso analítico e interpretativo dado aos fatos lingüísticos.

\section{Quem fala na Delegacia da Mulher?}

\subsection{A mullher fala}

A vítima de violência doméstica começa a construir sua voz quando decide fazer a denúncia e sai do seu espaço físico, doméstico e se dirige a DDM Seu discurso não é formulado no momento do depoimento, antes, vem sendo construído no trajeto entre a casa e a delegacia, entre o silêncio e o rompimento dele. A delegacia, embora da mulher, não deixa de ser um distrito policial e a história daquela mulher que ocorria na esfera do doméstico, portanto do privado, adentra a esfera pública.

Os fragmentos dos depoimentos que apresentaremos a seguir serão antecedidos de um breve relato do caso. Vítimas e escrivãs serão identificadas por iniciais ${ }^{10}$ :

Depoimento 1: "M" foi agredida fisicamente pelo marido, um agente penitenciário. Ela prestou depoimento em horário agendado

$\overline{10}$ Como já explicado anteriormente, mantivemos as identificações em sigilo absoluto. 
(portanto já havia estado na delegacia anteriormente, ocasião em que fora orientada a providenciar exame de corpo de delito e apresentar testemunhas), munida do resultado do exame de corpo de delito. "C", uma investigadora de polícia, assume o papel de escrivã e faz o atendimento. Esse depoimento, coletado na sala de recepção, foi o primeiro a ser gravado e " $M$ " a primeira mulher a ser convidada a participar da pesquisa. O depoimento de "M" com a lavratura do B.O. e T.C. durou 48 minutos. "M" optou por não representar contra o marido, ou seja, desistiu do processo .

Depoimento 2: "L" apanhou do marido porque se atrasou para chegar em casa no retorno do trabalho. "B”, escrivã de polícia, fez o atendimento em 52 minutos, na sala de depoimentos. Esse também era um depoimento agendado. A vitima optou por representar contra o autor, ou seja, deu prosseguimento ao processo.

Depoimento 3: "S", casada há 27 anos com "A", sofreu ameaça de morte do marido. Ele não quer que ela trabalhe fora e não admite o pedido de separação da mulher. Prestaram depoimento, nesse caso, a testemunha " $\mathrm{M}$ " e o indiciado "A". Os depoimentos foram registrados por "R", na sala de depoimentos.

Depoimento 4: "R", menor, foi agredida pelo pai ao tentar defender a mãe"I" de mais uma violência. Tratou-se de um atendimento agendado ocorrido na sala de depoimentos. Somente a mãe foi ouvida. Mãe e filha retiraram a queixa.

Nos atendimentos agendados, a escrivã lia o rascunho feito no primeiro atendimento - nem sempre realizado por ela mesma - e iniciava o questionamento sem nenhum tipo de introdução, o assunto era diretamente abordado:

\section{Depoimento 1}

1. Escrivã C. sem testemunha ... registra pra fica arquivado ((respondendo a uma pergunta de outra agente policial))

2. Agente. ahn... tá legal ((vozes))

3. Escrivã C. ((dirigindo-se a M)) ce trouxe o laudo ou não?

4. Vitima $M$. trouxe

5. Escrivã C. tá ((vozes)) 
Rev. ANPOLL, n 18, p. 183-216, jan./jun. 2005.

6. Vitima M. tem o raio xix... precisa?

7. não...só::o laudo..só

\section{Depoimento 2}

1. Vítima L. ((dirigindo-se à pesquisadora)) ahn ... o RG não sei de cor

2. Pesquisadora. Não tem problema... é só assinar

3. Vítima L. Não tem problema?

4. Pesquisadora. não precisa ((barulho no ambiente))

5. Vítima L. ( ) eu mudei ( ) não faz mal?

6. Pesquisadora. obrigada

7. Escrivã B. você:: ...... ele/ você entregou ... ... ele recebeu a intimação?

8. Vitima L. entreguei ... inclusive hoje ele saiu de casa ... eu achei que ele vinha né

\section{Depoimento 3}

1. Escrivã R. ((dirigindo-se à pesquisadora)) desliga um pouquinho seu gravador

2. Pesquisadora ( )

3. Escrivã R. não só pra eu te falar uma coisa ((o gravador é desligado))

((vozes no ambiente, som de rádio))

4. Escrivã R. (sei lá) se você quiser deixar desligado na hora que eu perguntar e liga pra não ficar ( )

5. Pesquisadora. não não pode deixar tudo bem (deixa ligado mesmo tudo bem)

((após 3min50seg, com barulho de máquina de escrever))

6. Escrivã R. ((dirigindo-se à vítima)) profissão?

7. Vitima S. caberereira

\section{Depoimento 4}

1. Escrivã P. qual que é qual que é o nome do pai dele?

2. Vítima I. o pai dela?

3. Escrivã P. o pai do ((diz o nome do filho))

Nessas interações, vitima e escrivã compartilham um conhecimento e não demonstram dificuldade em entender o tópico discursivo. O sentido dos enunciados é dado pelo contexto formado não só por aquela situação imediata, mas iniciado pelo primeiro contato daquela mulher com a delegacia e pelo rascunho desse primeiro 
MELo, Rosineide de. Interfaces oral e escrita na delegacia da mulher

contato anotado no "resumo" do qual se utilizava a escrivã para situar-se naquela segunda interação.

Destaca-se já no inicio desses depoimentos o papel da pesquisadora interferindo no processo interacional e causando um certo desconforto para vitimas e escrivãs. A escrivã $R$. foi a que se sentiu mais incomodada com a presença da pesquisadora e do gravador. Quanto a esse aspecto não é possível mensurar o quanto o processo interacional foi alterado em função da presença da pesquisadora, podemos afirmar, no entanto, que a pesquisadora e seu gravador foram elementos estranhos na rotina de trabalho das escrivãs e das próprias vítimas.

Os questionamentos da escrivã para a vítima seguiam um roteiro, embora não houvesse procedimento escrito para isso, percebemos uma estabilidade na ordenação das perguntas: primeiro, dados pessoas da vitima, em seguida, dados pessoais do autor, situação atual do casal após o primeiro atendimento, confirmação do primeiro relato sobre a agressão, questionamento sobre a continuidade ou não do processo.

A queixa relatada pela vítima é marcada por uma reclamação, em tom de denúncia e revolta, se comparada ao depoimento do agressor, que assume um discurso de justificativa. Nos depoimentos, prevaleceu a estrutura composicional narrativa, em que a sucessão dos fatos era marcada por verbos no pretérito e pelo uso do discurso citado. Nos relatos, a vitima atualizava a situação vivida na agressão e sua memória discursiva trazia a voz do agressor. Essas ocorrências no corpus confirmam que:

O falante, contando fatos passados, introduz a enunciação de um terceiro sob uma forma independente da narrativa, isto é, na forma que ela teve no passado. Fazendo isso, o falante transforma o presente da enunciação em imperfeito, para mostrar que a enunciação é contemporânea dos acontecimentos relatados. Depois ele realiza outras transformações (das formas pessoais do verbo, dos pronomes) para que não se pense que 
Rev. ANPOLL, n 18, p. 183-216, jan./jun. 2005.

se trata da enunciação do próprio narrador (BAKHTIN, 1995, p. 185).

Vejamos essas ocorrências:

Depoimentol, turnos 154, 160-162

154. Vítima M. é que nós fomos numa festa... num noivado né e lá ele começou a beber beber sabe? e aí eu convidei ele pra vir embora... tô chamando e ele na::da... nada ai eu cansei e falei então vou eu embora ..Aí quando eu cheguei no carro né ele veio atrais de mim aí eu pedi a chave pra eu ir embora a pé... aí ele me deu a chave já me deu com um soco... né ((vozes de outros depoimentos)) a:í: tudo bem... peguei a chave e fui embora e falei... ele vai voltar... ele quer beber ele que fique lá bebendo né... aí quando eu cheguei em casa ele já tAva em casa... no portão... ca:rro aberto... no úl:timo volume... ((assovio cantarolado no ambiente)) ele entrou atras de mim chutando tUdo.. chutando portão... chutando porta ... quebrou janela... né ... e aí ((vozes)) ele começou a me espancar... aí eu chamei a polí:cia ele me deu um murro no olho... né... sem contar ((escrivã reinicia a datilografia)) que ele dirige alcoolizado quando ele tá assim... eu já venho a pé porque se eu entrasse no carro com ele... ele ia tacar aquele carro lá::... no posti... que ele já... já... acostuma né querer dar uma de louco... assim quando tá... ... nervoso (é difícil) chamar amigo nosso né pra pra acalmar... porque se não... ele... ... ia fazer uma loucura lá... ...... além dele espancar ele quer

quebrar tudo tudo... o escândalo que ele faz... a rua toda ouve... "e aí eu convidei ele pra vir embora ... to chamando e ele na::da ... nada

aí eu cansei e falei então vou eu embora ..." $\longrightarrow$ dissonância, enunciativa: narrativa do autor + discurso no presente, ciprópria citação tação própria citação da situação de agressão

159. Escrivã C. - depois disso ele ameaçou... quando você falou que ia chamar a polícia ele te ameaçou de

160. Vítima M -
161. Escrivã C. - $\quad \begin{aligned} & \text { morte } \\ & \text { é durante a briga }\end{aligned}\left[\begin{array}{l}\text { é que ele falava } \\ \text { ahn }\end{array}\right.$

162. Vítima M. - o tempo todo você deu sorte que eu não tô com a arma aqui.. se:eu tivEvesse com a arma eu ia descarregar na sua boca... des- 
MeLo, Rosineide de. Interfaces oral e escrita na delegacia da mulher

carregar no seu ouvido... mas sem mais sem menos... ele... começa.... assim por nada... e ele tem porte de arma né... é que no momento ele tá sem arma... ((vozes e barulho da máquina de escrever))

"é que ele falava o tempo todo você deu sorte que eu não tô com arma aqui..." $\rightarrow \mathrm{DD}$

Depoimento 2, turnos 20, 162, 179, 198, 200

20.Vitima L. - eu ia trazer ... mas é a minha patroa ... e ela infelizmente ficou impossibilitada de vim ... é que nesse dia ... eu tinha ido acompanhar um sobrinho da minha patroa até a Santa Casa ... né .... e cheguei tarde... um pouco que eu cheguei atrasada: quando eu apertei a campainha ele abriu o portão perguntano onde eu estava: antes d'eu resPONder direito ele já foi me dando um soco... foi onde que eu não agüentei

"perguntano" $\longrightarrow$ DI, introduzido pelo gerúndio

162. Escrivã B.- ahn e você nun:::ca:://

163. Vítima L. -

eu não dava parte e ele falava se você der parte de mim um dia eu te corto o pescoço

\section{"ele falava se vocé der parte de mim um dia eu te corto o pescoco" \\ DD, percebido pelo verbo e introduzido pela diferença de entonação}

179. Vitima L. - obscenas::: .. ai você não agüenta.. aí também eu revido ... aí chega uma hora que onde vem pra cima ai ele bate ... entendeu ... eu nunca vim atrais porque eu falava nã::o um dia::: eu acabo com::: isso::: um dia acabo com isso ... ah se você for um dia ... você vai ver

"eu falava|nã::o um dia::: eu acabo com::: isso::: um dia acabo com isso ..." a entonação demarca a citação

DD, in̉troduzido pelo verbo, reformulando sua própria citação

Nesse mesmo turno, há a presença do DIL, que é percebido pela mudança de pessoa "eu" para "você", ou seja, da fala citada da própria depoente para a fala do marido, e pelo contexto. "L" drama- 
Rev. ANPOLL, n' n $^{\circ}$ 18, p. 183-216, jan./jun. 2005.

tiza o diálogo que supostamente manteve com o marido no momento da discussão, da situação de agressão. O "tom" ameaçador que caracteriza o enunciado posterior à sua citação, situacionalmente, só pode ser do marido:

"ah se você for um dia ... você vai ver" $\longrightarrow$ DIL

197. Escrivã B. - que você foi pra casa dela ... LAÁ que você solicitou a:::

198. Vítima L.-

e lá na casa dela ... eu mal saí da casa dela acho que não deu dois/ não deu cinco minutos ... sô subi em casa ... dali a pouco eu já voltei ... ela ((diz o próprio nome em vocativo)) que é isso? que ela me chama de ((diz o nome)) a::: eu mal cheguei ele me perguntou onde eu estava ...e jâ foi logo me agredindo ... aí ela falou não vamos deixar isso pra trás... eu vou lá falar com ele ... foi lá ... ele não deu ouvidos quase pra ela ... e (só o que falou ) ela é semvergonha mesmo ... me chamou de sem-vergonha ... ba ... bateu quase que o portão na cara da mulher ... e desceu e falou não ((diz o próprio nome em vocativo)) vamos na delegacia ... aî chamou a polícia ... a polícia veio... falou cê vai no pronto socorro ... passa pelo médico e amanhã vai na na delegacia ((ri)) da mulher

Atualizando novamente a situação de agressão para aquela interação, "L" recorreu ao DD e trouxe a voz da patroa que testemunhou a agressão:

“... ela ((diz o próprio nome em vocativo)) que é isso?” $\longrightarrow$ Embora omitindo o verbo introdutor, trata-se de DD

Os próximos enunciados do turno são em DD e DI e mesclam três enunciações: a do depoimento em si com aquela do diảlogo com a patroa após a agressão e a enunciação da situação de agressão:

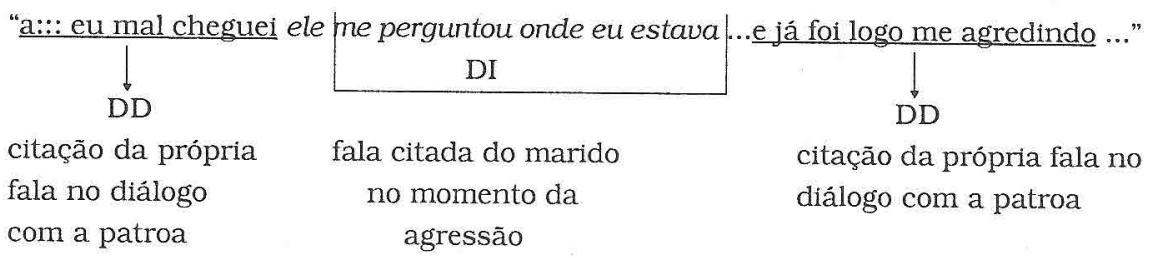


Melo, Rosineide de. Interfaces oral e escrita na delegacia da mulher

"aí ela falou não vamos deixar isso pra trás... eu vou lá falar com ele ..." $\rightarrow$ DD: verbo + entonação

"e desceu e falou não ((diz o próprio nome em vocativo)) vamos na delegacia ..." $\rightarrow$ DD

"a policia veio... falou cê vai no pronto socorro ... passa pelo médico e amanhã vai na na delegacia ((ri)) da mulher" $\rightarrow$ DD: voz da autoridade

O discurso citado em si já traz um processo de reformulação, portanto, a vítima traz para o presente da enunciação aquilo que passou pelo seu crivo, pela sua apreciação . De uma forma geral, as mulheres relatam aquilo que vai legitimá-las no papel de vitima. Inerentemente, já existiram apagamentos da situação de enunciação da agressão por esquecimento, por vergonha, por medo, constrangimento - não se relata tudo, primeiro, porque a enunciação é irrepetivel; segundo, porque esse não é o primeiro depoimento (omissões e acréscimos devem ter ocorrido em relação ao primeiro depoimento).

Há um ritual de negociação implícito na situação interacional: o discurso da vítima precisa ser convincente, a escrivã precisa acreditar que sua reclamação é verdadeira, daí a recorrência às vozes de outras enunciações para respaldar sua queixa, seu depoimento, seu papel interacional e social.

A voz da mulher-vítima aparece! Mas aparece acompanhada da voz do outro!

Considerando o recorte oral, o exame permitiu constatar que os discursos construídos e que circulam na DDM são estruturados em discursos citados: recortados, reformulados, ampliados e/ou reduzidos, cujo papel é o de dar (pseudo) veracidade, objetividade e realidade à queixa. O recurso do discurso citado dá uma falsa impressão de objetividade, pois uma vez que jâ foi reformulado, não é puro, nem neutro, já adquiriu sentidos heterogêneos empregados pela própria situação de enunciação, pelas coerções, pela avaliação pessoal das mulheres, pelas necessidades emocionais, sociais, fi- 
Rev. ANPOLL, $\mathrm{n}^{\circ}$ 18, p. 183-216, jan./jun. 2005.

nanceiras, ideológicas, pelo objetivo com o qual está sendo utilizado, ou seja, com vistas a quem esses discursos se dirigem. Mas é por intermédio dessa forma de discurso que a mulher se faz ouvir.

\subsection{Em nome da mulher ou em nome da instituição}

O Boletim de Ocorrência e o Termo Circunstanciado são documentos elaborados pelas escrivãs a partir dos relatos orais de vitimas. A função das escrivãs é transformar a linguagem cotidiana das vitimas em linguagem jurídica, formalizada por intermédio desses dois documentos, a fim de que o juiz leia, entenda, julgue e dê a sentença. O juiz só reconhece um fato se este tiver "traduzido" em termos jurídicos:

Cada esfera conhece seus gêneros, apropriados à sua especificidade, aos quais correspondem determinados estilos. Uma dada função (científica, técnica, ideológica, oficial, cotidiana) e dadas condições específicas para cada uma das esferas da comunicação verbal, geram um dado gênero, ou seja, um dado tipo de enunciado (BAKHTIN, 1997, p. 238-384).

Os enunciados que compõem o B.O. são padronizados e de um estilo cristalizado. Quanto à forma composicional, não há uma variação sintática e parte do léxico é recorrente em todos os boletins. A primeira parte do documento é composta por dados pessoais dos envolvidos e no verso há o "histórico":

Histórico do B.O. referente ao depoimento 1:

Comparece a ofendida, neste Distrito Policial, informando que convive maritalmente com o ofensor há cerca de 17 anos e possue dessa união 02 filhos; a vítima informa que seu marido faz uso de bebidas etílicas tornando-se muito agressivo quando ébrio; que na data dos fatos, por motivos a serem devidamente apurados no termo circunstanciado, o ofensor agrediua fisicamente causando-lhe lesões de natureza aparentemente leve além e ameaça-la de morte. 
Melo, Rosineide de. Interfaces oral e escrita na delegacia da mulher

Histórico do B.O. referente ao depoimento 2:

Comparece a esta Delegacia a vitima retro qualificada informando que convive maritalmente com o autor há 12 anos, sobrevindo a essa união um filho. Esclarece que na data dos fatos, por motivos a serem devidamente apurados, agrediu-a fisicamente, causando-lhe assim, lesões corporais de natureza aparentemente leve. Elaborado Termo Circunstanciado conforme ditame da Lei 9.099/95.

Histórico do B.O. referente ao depoimento 3:

Segundo consta, vitima e indiciado convolaram núpcias há vinte e sete anos, sobrevindo a essa união três filhos; alega que o marido é pessoa extremamente violenta e no curso da convivência matrimonial várias foram as desavenças, entreveros, desentendimentos, ameaças de morte e agressōes fisicas, as quais nunca foram registradas em quaisquer Unidade Policial; alega que não suportando mais as humilhações sofridas optou pela separação judicial e/ou consensual do casal, porém, em dia, horário e local retro mencionados, quando o indiciado foi cientificado de sua decisão, acabou por ameaça-la de mal injusto e grave, pois não concebe a idéia de dividir os bens angariados durante o matrimônio. Elaborado o Termo Circunstanciado e remetido ao Fórum Local com as cautelas de estilo.

Histórico do B.O. referente ao depoimento 4:

Comparece nesta Delegacia as vítimas retro qualificadas informando que a $1^{a}$ vitima é casada com o autor há cerca de 18 anos; sobrevindo a esta união três filhos; que a $2^{a}$ vitima é filha do casal. Informa que o referido faz uso freqüente de bebidas alcoólicas, e quando ébrio torna-se violento; que o mesmo já agrediu anteriormente, porém a esposa nunca registrou tais fato. Que na data dos fatos, durante discussão entre o casal, o autor a ameaçou de agressão; que a $2^{\text {a }}$ vítima foi em defesa da mãe e acabou sendo agredida pelo autor. Elaborado Termo Circunstanciado conforme ditames da Lei 9.099/95.

Embora o estilo traga traços da marca da individualidade do sujeito do enunciado, submete-se às coerções do estilo maior - do gênero. Com exceção do histórico 3, cuja redação é mais elaborada, com utilização de termos mais arcaicos e estrutura mais rigorosa, os demais históricos possuem um estilo e uma forma composicional 
Rev. ANPOLI, no 18, p. 183-216, jan./jun. 2005.

muito próximos. O discurso citado na forma de DI novamente é a base estrutural do enunciado da escrivã:

"Comparece a ofendida ... informando que ... a vítima informa que... que na data dos fatos" (B.O. 1)

“.... a vitima retro qualificada informando que ... esclarece que...." (B.O 2)

"Segundo consta .... alega que ..." (B.O. 3)

"As vitimas retor qualificadas informando que ... informa que ..." (B.O. 4)

As designações "vitima", "autor", "indiciado" e a autodesignação, pela escrivã, de "autoridade policial" aparecem somente no registro escrito. Essas designações são determinadas pela Lei dos Juizados Especiais Criminais, a qual as DDM"s se submetem. Pela legislação penal, "vítima" e "ofendido(a)" designam a mesma pessoa, embora "ofendido(a)" fosse mais comum no Código Penal do Império e do Republicano, segundo BAPTISTA (1997, p.30).

Em relação às designações de "autor", "acusado" , os Artigos 58 e 69 e 68,78 e 81 da Lei dos Juizados Criminais determinam, respectivamente, que "na frase preliminar, o sujeito da infração é chamado de 'autor do fato'; no processo sumarissimo, de 'acusado"” (JESUS, 200, p. 76).

A autodesignação "autoridade policial" é prevista pela Legislação:

O art. 69 da Lei n. 9.099, ao dispor que "a autoridade policial que tomar conhecimento da ocorrência lavrará termo circunstanciado e o encaminhará imediatamente ao Juizado (...) . E inequivoco que o legislador, ao tratar o inquérito policial no Código de Processo, empregou a expressão "autoridade policial" para designar os agentes públicos com poderes administrativos para a presidência do inquérito, lavratura de auto de 
Melo, Rosineide de. Interfaces oral e escrita na delegacia da mulher

prisão em flagrante, requisições de exames periciais, audiência de testemunhas, interrogatório do indiciado, reconhecimento de pessoas e coisas etc. (JESUS, 200, p.39).

A utilização dessas designações, portanto, ocorre em função de uma exigência da linguagem jurídica determinada por lei, uma coerção do gênero.

O Termo Circunstanciado é o segundo documento gerado a partir do depoimento e do B.O. É constituído por folhas timbradas com o brasão do estado de São Paulo e identificadas pela Secretaria de Segurança Pública, da Polícia Civil e da Delegacia da unidade. Não há nenhum campo para preenchimento: os fatos são registrados ocupando todo o espaço em branco, obedecendo ao espaçamento de parágrafos. Lembramos que no caso da unidade pesquisada, os registros eram datilografados com carbono entre as folhas. A primeira parte é composta de informações sobre a ocorrência (tipo, data, local). A narrativa sobre os fatos possui uma introdução com forma composicional relativamente estável e estilo que correspondem à linguagem jurídica:

DOS FATOS: Chegando ao meu conhecimento através do Boletim de Ocorrência $n^{\circ} .$. [resumo do ocorrido] (enunciado constante nos T.C's referentes aos depoimentos 1,2 e 4 ).

DOS FATOS: Chegando ao conhecimento desta Autoridade Policial através do Boletim de Ocorrência $\mathrm{n}^{\circ}$... (enunciado do TC referente ao depoimento $3)$.

A segunda parte do T.C. é destinado ao registro do depoimento da vítima. A escrivã inicia a redação com o nome da vítima e os dados pessoais ( $R G$, nacionalidade, cútis, idade, estado civil, data de nascimento, naturalidade, filiação e endereço). Em discurso citado, com predominio de estrutura do DI, a escrivã registra o depoimento da mulher: 
Rev. ANPOLL, $\mathrm{n}^{0} 18$, p. 183-216, jan./jun. 2005.

VÍTIMA: [nome], [dados pessoais]. Estando presente nesta, argüida pela Autoridade Policial, respondeu haver convolado núpcias com o autor.... A declarante afirma que ... [informa que] (depoimentos 3 e 4)

VÍTIMA: [nome], [dados pessoais]. Presente nesta, argüida pela Autoridade Policial, respondeu: que convive maritalmente como autor há .... Esclarece a declarante que o amásio ... [ a ofendida consigna que ] (depoimentos 1 e 2)

Ao final do relato, a escrivã informa se a vítima quer representar ou não contra o autor. Encerra-se essa parte com uma linha demarcando o local para assinatura da vítima. Nos casos em que a vítima deseja dar prosseguimento ao processo, a escrivã chama a testemunha - se houver - e registra o depoimento desta, iniciando a redação com a mesma estrutura composicional;

TESTEMUNHA:[nome, dados pessoais] ...Estando presente nesta disse...

O final do registro do depoimento é seguido também por uma demarcação para assinatura. Em seguida, obedecendo ao estilo e à forma composicional, registra-se o depoimento do autor.

AUTOR: [nome dados, pessoais]. Estando presente nesta, arquido pela Autoridade Policial, respondeu"...

A parte final do T.C. é destinada às PROVIDÊNCLAS (documentos anexados) e à CONCLUSÃO (parecer da escrivã sobre o fato, invocando os artigos do código penal que foram infringidos pelo autor). O T.C. é encerrado com os enunciados; REGISTRE-SE E CUMPRA-SE, Local e data, cargo e nome da delegada, cargo e iniciais da escrivã de polícia, seguidos de sua rubrica. Posteriormente, a delegada também assinará o B.O. e o T.C.

Sob a forma escrita, a escrivã assume o papel de porta-voz da vítima: via discurso citado, fala em nome da mulher dirigindo-se ao juiz - grande interlocutor desses discursos e razão pela qual esses discursos são construídos dessa forma, nesse estilo. No entanto, ao reformular o discurso oral da vítima, a escrivã, inevitavelmente, já 
Melo, Rosineide de. Interfaces oral e escrita na delegacia da mulher

alterou esse discurso, não só em função da passagem oral/escrito, mas fundamentalmente, porque os sujeitos discursivos implicados já não são os mesmos: a mulher fala para a escrivã ; a escrivã fala para o juiz. O objetivo da mulher, na interação, é fazer uma queixa, uma denúncia, romper com o silêncio e com uma provável situação de opressão doméstica; o da escrivã, registrar uma ocorrência, cumprindo seu papel profissional. Atravessados pelo discurso jurídico, inseridos no ambiente de uma delegacia, surgidos de uma dada situação imediata, mas não menos envolvidos pelo contexto maior, os discursos das mulheres já não são mais somente vozes das vitimas, mas sim discursos em que prevalecem as vozes das autoridades policiais, portanto, da instituição. Esse discurso construído pela instituição não é neutro, nem objetivo, já está embuído do tom apreciativo, das omissões, acréscimos, das avaliações jurídicas, legais e até pessoais do sujeito daquele "novo" enunciado.

Cotejando os três fatos lingüisticos - depoimento oral, B.O. e T.C. pudemos examinar a reformulação de sentido que se deu do oral para o escrito. Vejamos algumas dessas ocorrências: no depoimento 1 , notamos que a escrivã omitiu a informação de que o marido de "M" possuia arma de fogo, descaracterizando-o, portanto, como um ameaçador em potencial. A escrivã utilizou palavras como "amásio", "ébrio", "bebidas etílicas", pouco comuns na linguagem cotidiana, e que são carregadas de carga semântica pejorativa. "Amásio" ressalta a condição da mulher de descasada, ainda fator de discriminação na sociedade brasileira. No depoimento 2 , "L" diz de forma modalizada que o marido possui o vício de beber; a escrivã registra que "o amásio é desprovido de vício". No depoimento 3, na parte da testemunha, a escrivã inicia o registro com sua apreciação valorativa explícita ao desconsiderar o testemunho: "Estado presente nesta, às de costume disse nada”, dessa forma, já predispõe o juiz a considerar aquela declaração desnecessária. No depoimento 4 , aprecem detalhes do caso que não foram ditos pela vítima na oca- 
Rev. ANPOLL, $n^{\circ}$ 18, p. 183-216, jan./jun. 2005.

sião daquela interação, inferimos que a escrivã recorreu à memória discursiva do caso.

Para confirmar nossa análise, apresentaremos fragmentos de depoimentos orais em comparação aos seus respectivos registros escritos:

\section{Guadro 2 - Oral x Escrito}

\begin{tabular}{|c|c|}
\hline Depoimento 1 & Termo Circunstanciado \\
\hline $\begin{array}{l}\text { 69. Escrivã C. - ele bebe muito... faz há } \\
\text { muito tempo que ele bebe? } \\
\text { 70. Vitima M. ele não é um alcoólico...ele } \\
\text { bebe...assim em festas...finais de semana né } \\
\text { mas é uma pessoa extremamente violenta } \\
\text { quando bebe... } \\
\text { 71. Escrivã C. - sempre foi assim durante } \\
\text { esse casamento ou não? } \\
\text { 72. Vitima M. - olha:: já... ameaça já teve } \\
\text { várias... i:... cada... depois que ele começou } \\
\text { a trabalhar nessa penitenciária... eu acho } \\
\text { que ele não tá separando...ele tá trazendo } \\
\text { muito problema... pra casa... e tá piorando } \\
\text { 154. Vítima M. - é que nós fomos nuna fes- } \\
\text { ta... num noivado né e lá ele começou a } \\
\text { beber beber sabe? e aí eu convidei ele pra } \\
\text { vir embora... tô chamando e ele na::da... } \\
\text { nada ai eu cansei e falei então vou eu embo- } \\
\text { ra ...Ai quando eu cheguei no carro né ele } \\
\text { veio atrais de mim aí eu pedi a chave pra eu } \\
\text { ir embora a pé... aí ele me deu a chave já } \\
\text { me deu com um soco... né ((vozes de outros } \\
\text { depoimentos)) a:í: tudo bem... peguei a } \\
\text { chave e fui embora e falei... ele vai voltar... } \\
\text { ele quer beber ele que fique lá bebendo né... } \\
\text { aí quando eu cheguei em casa ele já tAva } \\
\text { em casa... no portão... ca:rro aberto... no } \\
\text { úl:timo volume... ((assovio cantarolado no } \\
\text { ambiente)) ele entrou atras de mim chutan- }\end{array}$ & $\begin{array}{l}\text {... que na data dos fatos, seu amásio } \\
\text { estava alcoolizado e após um desen- } \\
\text { tendimento entre o casal, o autor } \\
\text { agrediu-a desferindo-lhe um soco } \\
\text { no olho direito além de chutes e } \\
\text { murros pelo corpo da ofendida cau- } \\
\text { sando-lhe lesões de natureza apa- } \\
\text { rentemente leve. A ofendida consi- } \\
\text { ga que no auge da discussão ele } \\
\text { ameaçou-a de morte. }\end{array}$ \\
\hline
\end{tabular}


do tUdo.. chutando portão... chutando porta ... quebrou janela... né ... e aí (((vozes))) ele começou a me espancar... aí eu chamei a polícia ele me deu um murro no olho... né... sem contar ((escrivão reinicia a datilografia)) que ele dirige alcoolizado quando ele tá assim... eu já venho a pé porque se eu entrasse no carro com ele... ele ia tacar aquele carro lá::... no poste... que ele jâ... já... acostuma né querer dar uma de louco... assim quando tá... ... nervoso (é difícil) chamar amigo nosso né pra pra acalmar... porque se não... ele... ... ia fazer uma loucura lá... ....... além dele espancar ele quer quebrar tudo tudo... o escândalo que ele faz... a rua toda ouve...

155. Escrivã C. - é o direito né?

156. Vítima M. - foi o direito

157. Escrivã C. - chute...murro...né que a senhora falou

158. Vítima M. - ele deu chute... dá: murro... ele::: eh onde pegá... ... e ele é:::uma pessoa::: treinada né... ele tá ne:sse meio né é:: es:preparado... ele sabe onde bater 159. Escrivã C. - depois disso ele ameaçou... quando você falou que ia chamar a polícia ele te ameaçou de morte 160. Vítima M - é durante a briga é que ele falava

161. Escrivã C. - ahn

162. Vítima M. - o tempo todo você deu sorte que eu não tô com a arma aqui.. se:eu tivEvesse com a arma eu ia descarregar na sua boca... descarregar no seu ouvido... mas sem mais sem menos... ele... começa.... assim por nada... e ele tem porte de arma né... é que no momento ele tá sem arma... ((vozes e barulho da máquina de escrever)) 
Rev. ANPOLL, n 18, p. 183-216, jan./jun. 2005.

\begin{tabular}{|c|c|}
\hline Depoimento 2 & Termo Circunstanciado \\
\hline 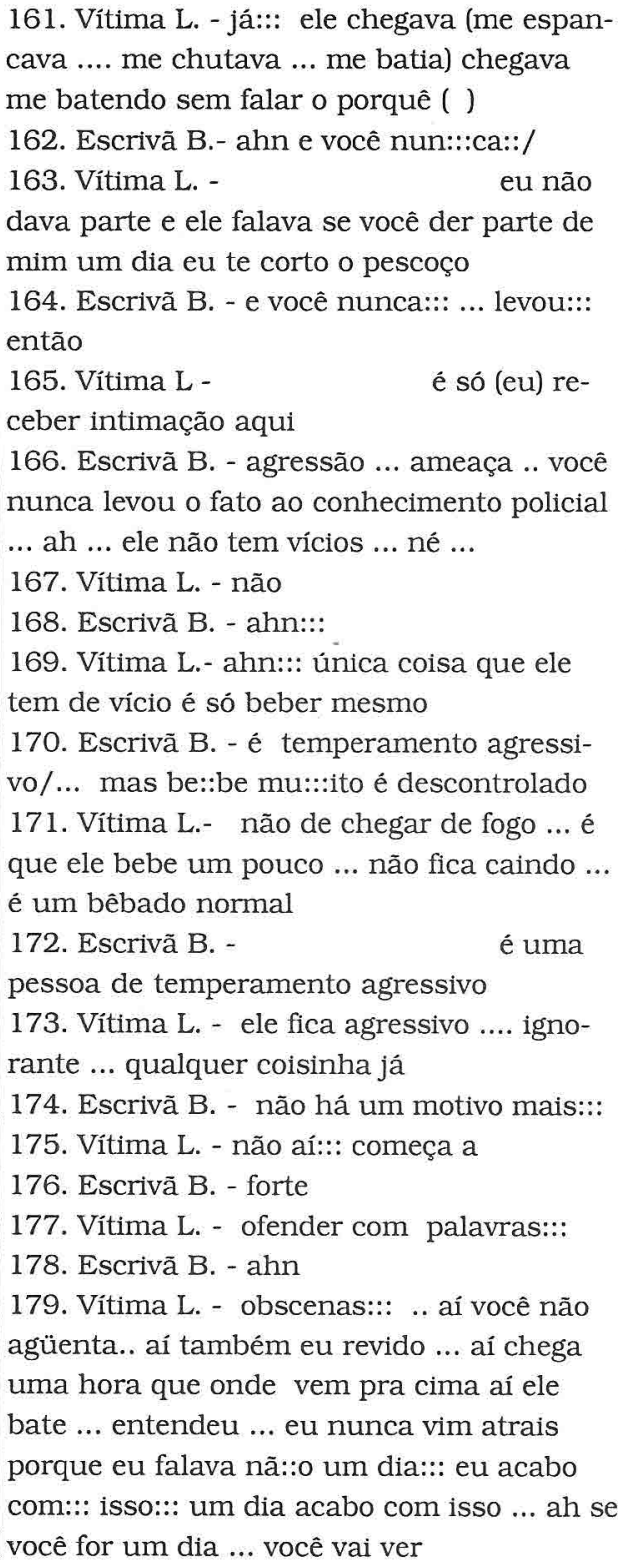 & $\begin{array}{l}\text {... Esclarece a declarante que o } \\
\text { amásio é pessoa desprovida de ví- } \\
\text { cios, contudo, de temperamento } \\
\text { agressivo e explosivo. Que já agre- } \\
\text { diu-a fisicamente diversas vezes, } \\
\text { bem como proferiu-lhe ameaças de } \\
\text { morte, porém, nunca levou os fatos } \\
\text { a conhecimento policial. }\end{array}$ \\
\hline
\end{tabular}


Meso, Rosineide de. Interfaces oral e escrita na delegacia da mulher

\begin{tabular}{|c|c|}
\hline Depoimento 3 (Testemunha) & Termo Circunstanciado \\
\hline $\begin{array}{l}\text { 11. Escrivã R. ((barulho de máquina por } \\
\text { 20seg)) acerca dos fatos que dona ((diz o } \\
\text { nome da vítima)) alega ter sofrido no dia } \\
\text { onze do nove ... onde seu ((diz o nome do } \\
\text { acusado)) ... que é marido dela teria a amea- } \\
\text { çado ... qual é ah seu conhecimento ... a } \\
\text { senhora viu ... a senhora soube? } \\
\text { 112. Testemunha M. - não ... eu sou a vizi- } \\
\text { nha dela há mais de cinco anos ... ela rela- } \\
\text { tou ... por telefone o que aconteceu e me } \\
\text { convidou pra eu ser testemunha aqui na } \\
\text { quinta-feira } \\
\text { 113. Escrivã R. - ah tá } \\
\text { 114. Escrivã R. - (então) a senhora tomou } \\
\text { conhecimento do fato através de narrativas } \\
\text { da própria vitima } \\
\text { 115. Testemunha M. - isso ... da própria } \\
\text { vitima } \\
\text { 116. Escrivã R. - a senhora já tinha um } \\
\text { outro conhecimento ou esse foi o primeiro? } \\
\text { 117. Testemunha M. - não ... ela já havia } \\
\text { comentado algumas vezes comigo } \\
\text { 118. Escrivã R. - é } \\
\text { 119. Testemunha M. - que ela tem o salão } \\
\text { né } \\
\text { 120. Escrivã R. - hum } \\
\text { 121. Testemunha M. - ela é cabelerera } \\
\text { 122. Escrivã R. - certo } \\
\text { 123. Testemunha M. - e eu sou cliente dela } \\
\text { e ela tinha comentado comigo ... como nós } \\
\text { somos mais íntimas ela já tinha ... falado } \\
\text { alguma coisa a respeito } \\
\text { 124. Escrivã R. que havia os desentendi- } \\
\text { mentos entre o casal } \\
\text { 125. Testemunha M. - isso já algum tempo } \\
\text { la já }\end{array}$ & $\begin{array}{l}\text {... Estando presente nesta, às de } \\
\text { costume disse nada. } \\
\text { Compromissada e inquirida pela } \\
\text { Autoridade, respondeu: ser vizinha } \\
\text { da vítima há cinco anos e em face } \\
\text { da profissão da mesma acabaram } \\
\text { se tornando amigas intimas e em } \\
\text { algumas ocasiōes a vítima teria } \\
\text { confidenciado à depoente que suas } \\
\text { relaçōes matrimoniais não encami- } \\
\text { nhavam bem ... tomou conhecimen- } \\
\text { to de que a vítima havia sido } \\
\text { ameaçada de mal injusoto e grave } \\
\text { pelo marido, através de narrativas } \\
\text { da referida num contacto via tele- } \\
\text { fone; a depoente afirma ter conhe- } \\
\text { cimento que o motivo que ensejou } \\
\text { a ameaça proferida pelo autor se- } \\
\text { ria a vítima ter optado pela separa- } \\
\text { ção legal do casal; a depoente de- } \\
\text { seja consignar que a vitima teria } \\
\text { narrado-lhe que o marido efetua as } \\
\text { ameaças contra a pessoa da espo- } \\
\text { sa em estando o casal a sós. }\end{array}$ \\
\hline
\end{tabular}


Rev. ANPOLL, n 18, p. 183-216, jan./jun. 2005.

lamentando há algum tempo ... mas ela não comenta com quase ninguém o fato só eu 127. Escrivã R. - ((barulho de máquina de escrever durante 1 min $45 \mathrm{seg}$ )) a senhora tem conhecimento de que ela optou pela separação? Que esse teria sido o motivo dela ter sido ameaçada pelo marido?

128. Testemunha M. - se eu tenho conhecimento?

129. Escrivā R. - isso

130. Testemunha M. - se e::la:: tá sim através da violência né

131. Escrivã R. - hum hum

132. Testemunha M. - que ela tá querendo separar ... primeiro ela falou que não queria sair ... agora ela tá querendo até abrir mão pra sair né .... então ... ele nega viu ... ele fala ... geralmente eles negam ... né ... ela comentou também ... que ele faz esse tipo de ameaça quando não se encontra ninguém na casa

113. Escrivã P. ((após 30seg)) cê é casada com ele há dezoito anos? tem três filhos?

114. Vítima I. - tenho

115. Escrivã P. - ele bebe?

116. Vitima I. - e::le bebe

117. Escrivã P. - isso acontece quando ele tá bêbado?

118. Vítima I. - é ... quando

119. Escrivã P. - ou é do temperamento dele?

120. Vítima I. - não ... quando ele bebe é que ele fica assim

121. Escrivã P. - só quando bebe?

122. Vítima I. - só quando bebe aí precisou nóis vim aqui por causa disto que ele estava agressivo co'a menina ... ai foi passado na delegacia e tudo

Termo Circunstanciado

... respondeu: haver convolado núpcias com o autor dos fatos há dezoito anos, sobrevindo a essa união três filhos; alega qu o marido faz uso de bebidas com teores etílicos e quando embriagado se torna extremamente violento, sendo que no curso do matrimônio já teria agredido-a fisicamente noutras ocasiões; (...) informa que o autor costumeiramente promove desordens no lar conjugal produzindo tormentos e deixando o relacionamento insustentável, inclusive aos filhos do casal; na data dos fatos o autor se encontrava visivelmente embriagado, passando a fomentar 
123. Escrivã P. - nesse dia aqui ele ameaçou você aí a filha foi te:: defender aí ela que acabou sendo agredida isso?

124. Vítima I. - é é foi isso aí ... é é 125. Escrivã P. - ((depois de 1 min25seg)) - já te agrediu outras vezes?

126. Vítima I. - já

127. Escrivă P. - cê nunca registrou nada?

128. Vîtima I. - não desavenças e desentendimentos no lar, iniciando-se assim uma discussão, onde no auge o autor ameaçou de agredir fisicamente a esposa, tendo inclusive levantando o braço para agredi-lá , momento em que a filha do casal interveio e acabou levando o tapa que inicialmente era destinado a sua mãe ...

\section{Conclusão}

Considerando as questões que nortearam nossa pesquisa: 1) como o processo reformulação do oral para o escrito contribui para a constituição de sentidos heterogêneos; 2) quais os elementos estáveis do enunciado que compõem a atividade discursiva da DDM; e 3) quais as pistas lingüisticas e extralingüísticas que revelam as vozes; concluímos que:

a) a mulher/vitima fala, na interação, de um lugar inferior ao da escrivã - uma vez que esta é "autoridade" policial. Mas essa mulher ocupa um status social correlacionado ao seu poder de iniciar e finalizar o processo. Seu discurso traz vozes do agressor, da violência doméstica, da moral religiosa, da história de discriminação e da luta das mulheres;

b) a escrivã fala pela mulher, fala pela instituição e fala para o juiz. Sua voz é um conjunto atravessado por muitos discursos; da mulher - a quem representa, da linguagem jurídica, da tradição policial. Pela própria inerência da reformulação, o discurso que a escrivã constrói não é o mesmo discurso da vítima - passa a ser o discurso institucional; o discurso da mulher se descaracteriza, mesmo a escrivã mantendo a descrição dos fatos e recorrendo ao discurso citado.A reformulação resignifica a voz da mulher: o que permanece é o discurso escrito na linguagem juridica, com a apreciação valorativa da escrivã - como representante da instituição policial; 
Rev. ANPOLL, $n^{\circ}$ 18, p. 183-216, jan./jun. 2005.

c) as muitas vozes que perpassam o discurso da/na DDM são marcadas pelo lingüístico: léxico, estrutura narrativa, uso de discurso citado; elementos do estilo da linguagem juridica do gênero, associado aos aspectos extralingüisticos que envolvem desde o ambiente situacional da interação até o contexto histórico, político, ideológico da criação e a manutenção das DDM's na sociedade brasileira;

d) o tema - na concepção bakhtiniana do termo, só pode ser percebido na amplitude concreta do momento histórico, considerando tudo que o envolve: trajetória do feminismo, ineficiência de uma política pública contra a violência, conquista da DDM, desafios da DDM, cenário dos depoimentos, situação interacional, voz reformulada que adquire outros sentidos. Assim compreendido, paradoxalmente, a DDM criada para defender a mulher, reitera a discriminação por intermédio das práticas discursivas. A discriminação constitui o tema do enunciado da esfera examinada.

ABSTRACT: The Delegacia de Defesa da Mulher (Women's Defense Police Station) was founded in the 80's aiming at helping women victimized by domestic violence. Our study tried to investigate the relationship between oral statements given by the women seeking for help in the Police Station and the respective Boletins de Ocorrência (Written Statement) and Termo Circunstanciado (Term of Occurrence) - written forms of registration made by the police officers. These formal and official forms of registrations follow a pattern of style and they seem not to report exactly the speech of the victim. Based on the concepts of dialogism and discourse genre of the Russian philosopher Mikhail Bakhtin and his circle, we propose to analyze how those speeches given by the women are reformulated and, in this process, they acquire different meanings.

KEY WORDS: discourse; reformulacion; voice; women 


\section{REFERÊNCIAS BIBLIOGRÁFICAS}

Authier-Revuz, J. (1998) Palauras incertas: as não-coincidencias do dizer. Trad. Claudia R. C. Pfeiffer et al. Campinas: Editorada da UNICAMP, 200 p.

Bakhtт, M. (Volochinov). (1995) Marxismo e filosofia da linguagem. Trad. Michel Lahud. Yara Frateschi Vieira. 7.ed. São Paulo: Hucitec, 196 p.

Bakhtin, M. (1997) Estética da criação verbal. Trad. Maria Ermantina G.G.Pereira. 2.ed. São Paulo; Martins Fontes, 421 p.

Baptista, M.P. (1997) Vitimologia. Dissertação de Mestrado em Direito Penal. São Paulo: Pontifícia Universidade Católica de São Paulo, 140 fls.

Barros, D.L.P. "Procedimentos de reformulação" In Pretr, Dino. (Org.). Análise de textos orais. São Paulo, FFLCH/USP, p. 129-156. (Projetos Paralelos - NURC/SP), v. 1.

FÁvero, L.L. "O tópico conversacional". In: In Preti, Dino. (Org.). Análise de textos orais. São Paulo, FFLCH/USP, p. 33-54. (Projetos Paralelos NURC/SP), v.1.

Jesus, D.E. (2000) Lei dos juizados especiais criminais anotada. 5.ed. ver. e atual. São Paulo: Saravia, 160 p.

Marngueneau, D. (1997) Novas tendências em análise do discurso. Trad. Freda Indursky. 3.ed. Campinas: Editora da UNICAMP/ Pontes, 198 p.

- (1998) Analyser les textes de communication. Paris: Duno.

Mero, R. (2001). Delegacia de Polícia: Defesa da Mulher? Um enfoque dialógico. Mestrado em Lingüística Aplicada e Estudos da Linguagem. São Paulo: Pontifícia Universidade Católica, 227 fls.

Rodrigues, A.C.S. "Lingua falada e lingua escrita". In: PRETI, Dino. (Org.). Análise de textos orais. São Paulo, FFLCH/USP, p. 13-32. (Projetos Paralelos - NURC/SP), v.1.

SÃO PAULO. Decreto n ${ }^{\circ}$ 29.981/1989. Diário Oficial do Estado de São Paulo, $1 / 6 / 1989$.

Urbano, H. "Marcadores conversacionais".In: In PretT, Dino. (Org.). Análise de textos orais. São Paulo, FFLCH/USP, p. 81-102. (Projetos Paralelos NURC/SP), v.1. 